\section{Percent of response}

If you're fortunate, I've been told, you will receive a response from about $30 \%$ of those you contacted. If you've targeted your audience carefully, you may receive a greater return. In my own case 1 mailed 121 questionnaires on January 19 and had received 57 responses by April 2, or $47 \% ; 60$ replies by May 1 , or $50 \%$

\section{Added benefits}

You'll probably receive responses that will make your day - colleagues who realize they have some of the same concerns you do. The next time you meet any of these people at a library conference, you'll greet each other a bit more warmly, sharing a bond of having helped each other try to solve problems of mutual concern.

While it may take more hours than you anticipate to prepare and/or collate the results, a survey can open new doors for you. If you are able to use the information gleaned as a basis for an article, be sure to give credit where credit is due. If another colleague or institution has been particularly helpful and would appreciate recognition, give it!

You may even be asked to share the results of your research with other colleagues at local, regional or national conferences. So, dear first-timeor tenth-time-surveyer, be prepared to add a "new dimension" to your life. A survey is well worth the effort!

\title{
To better the best and brightest undergraduates
}

\author{
By Myoung Chung Wilson \\ Information Services Librarian \\ Rutgers University
}

\author{
and Kevin Mulcahy \\ Reference Coordinator \\ Rutgers University
}

There is a renewed interest in improving the quality of undergraduate education in institutions of higher learning-especially in large, public, research universities where, it is alleged, laboratory work and grant dollars are often put ahead of students, teaching and learning, and where attention to undergraduates has a low priority. ${ }^{1}$ Some have also said that faculty members in this environment have little incentive to increase their teaching workload by making assignments that require close student supervision. ${ }^{2}$

In order to ensure high quality education, particularly that of undergraduates, the Council on Improvements on Teaching at Rutgers, the State University of New Jersey, annually solicits and funds projects that encourage creative and innovative instructional methods. A project that was proposed by three librarians ${ }^{3}$ at the Rutgers Alexander Library (the research library for the social sciences and humanities), entitled "Comprehensive Research Access Training: A Proposal to Enhance the Research Capabilities of Undergraduate Honors Students," was funded during the $1985-86$ aca-

\footnotetext{
${ }^{1}$ Scott Heller, "Ways to Improve Undergraduate Education Sought by New Alliance of State Universities," Chronicle of Higher Education, January 14, 1987, pp. 13-14.

${ }^{2}$ Susan H. Anthes \& Lawson Crowe, "Teaching Library Literacy," College Teaching 35 (Summer 1987):92-94.

${ }^{3}$ They are Marianne I. Gaunt, Kevin Mulcahy, and Myoung Chung Wilson.
}

demic year.

Undergraduate honors students were selected for participation in the project for the following reasons:

1) Nationally the needs assessments for bibliographic instruction require, among other things, identification of library user groups for whom a bibliographic instruction class or series of classes is targeted or designed. While undergraduates as a whole, and especially freshmen and academically disadvantaged students, are frequently identified as target groups for bibliographic instruction, little has been done with undergraduate honors students, i.e., those who seek academic excellence. The identification of this group for the purpose of bibliographic instruction is important because they tend to fall between the general undergraduate population and the more advanced graduate students and faculty.

2) At Rutgers University, where there has been an expansion of the undergraduate honors program and where a premium has been placed on interdisciplinary endeavor and independent research, neither the university nor the library has provided honors students with systematic training in the acquisition of new information and research materials, particularly by the utilization of new technology.

3) The honors students at Rutgers, as well as at other universities, are potential scholars at the very outset of their careers. An advanced comprehensive training in research techniques is considered essential for their future work. 


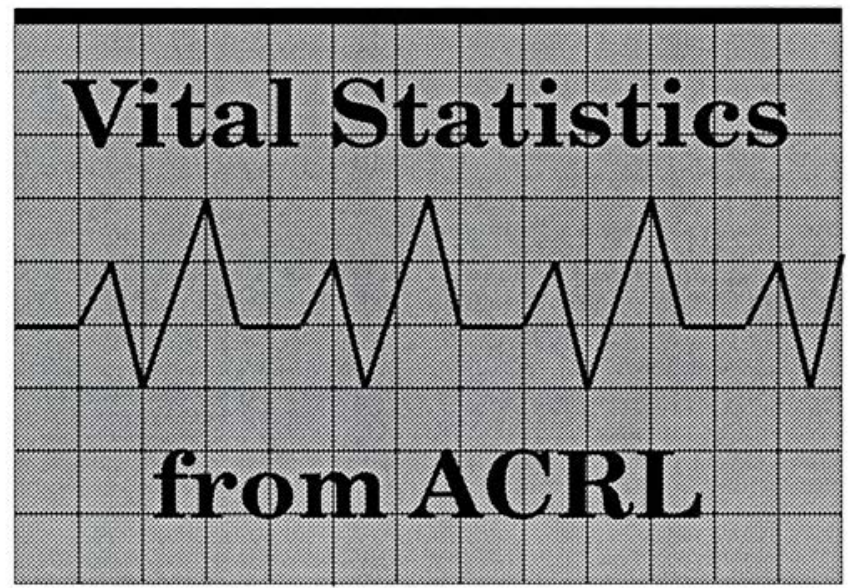

Library Statistics of Colleges and Universities, 1985:

National Summaries, State Summaries, Institutional Tables. Statistics on 3,000 academic libraries surveyed by the Center for Educational Statistics. Contains data on collections, operating expenditures, staff, and institutional indices of library operating expenditures, books and bound serials and FTE library staff. $\$ 30.00$ pb; ACRL member $\$ 24.00 \quad 240$ p. $\quad 0-8389-7147-4 \quad 1987$

ACRL University Library Statistics 1985-86 and 1986 "100 Libraries" Statistical Survey. Data and rankings of 149 university, college, community and junior college libraries on collections, expenditures, personnel, and interlibrary loans.

$\$ 30.00$ pb; ACRL member $\$ 24.00 \quad 110$ p. $\quad 0-8389-7144-x \quad 1987$

Quantitative Criteria for Academic Research Libraries, by Kendon L. Stubbs. Data from 3,000 academic libraries answers the question, "What is an academic research library?" In tables arranged by state, each institution is ranked by a component score. $\$ 19.00$ pb; ACRL member $\$ 15.00$ 135p. $\quad 0-8389-6788-4 \quad 1984$

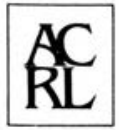

Association of College and Research Libraries A division of the American Library Association c/o ALA Publishing Services, Order Department 50 East Huron Street • Chicago, Illinois 60611-2795 


\section{Project description}

Through various university offices and with the cooperation of the directors of honors programs, a total of 32 students in ten different academic disciplines was identified for participation in the project. The level of these students ranged from those in the General Honors Program (freshman and sophomore) to those in the Henry Rutgers Honors Program, the oldest and most prestigious honors program open only to upper classmen. All of these participants were volunteers. Seven seminars, interspersed throughout Fall Semester 1985, were organized on the following subjects: commercially available computer databases; academic library information networks; machine-readable text/humanities; machine-readable data files; manuscript and archival materials; and government publications.

While the seminars as a whole were conducted by professional librarians (and the data archivist at the University Computer Center), the series was inaugurated by an informal talk given by a Rutgers University history professor, Warren Kimball, whose two-volume book on Churchill and Roosevelt had just been released by the Princeton University Press. Kimball was asked to participate because his ten years of research for this book had required a sophisticated knowledge of research materials.

The participants were required to attend at least two of these seven seminars in order to be eligible for the computer search services free of charge. ${ }^{4}$ During the term of the project, 97 computer searches were conducted in 33 databases. Students were asked to review the initial search results and were then asked to refine their research focus and, as necessary, return for additional searches.

\section{Evaluation and findings}

The response rate to mailed evaluation quiestionnaires and follow-up telephone calis was less than $50 \%$, with 13 out of 32 participating students and 11 out of 21 participating faculty advisors responding. Our findings from these responses included both surprises and expected results. We were surprised, for example, that none of the participating honors students had ever requested a computer search before and only two out of 13 wanted to be trained to conduct a search for themselves. We also found that honors students were less familiar with bibliographic sources than expected; they were far more familiar with library services in general. The computer search cost per student was not as high as anticipated- $\$ 68$ per student and $\$ 23$ per search are, in our opinion, acceptable for a serious research effort.

The honors students for the most part had reasonable expectations of what a computer search

Some funding for computer searches is available for undergraduate honors students at Rutgers. could deliver; faculty members were also realistic in their expectations, noting that even a good computer search could not compensate for inadequate research ability. One faculty member also pointed out that the quality of a computer search varied with students' success in focusing their research activities. Although we had originally intended to evaluate the search results with each student, we found that time constraints made this impossible.

\section{Conclusion}

The assumption that intellectually superior undergraduate honors students are also superior in their knowledge of bibliographic skills was not confirmed. The findings of this project suggest that undergraduate honors students need training in basic bibliographic skills; indeed they require more focused attention than the average student due to their higher research expectations. For some students, learning that a computer search might not be appropriate for their research topic was also a valuable lesson. Through this project we also hoped to train honors students to develop evaluative judgments concerning manual and computer literature searches. Educating students to select the most appropriate materials by the right method at the right time is, however, a skill that clearly goes far beyond learning how to gain access to computer databases alone. Access to computer facilities, therefore, cannot replace the general research skill of the students nor the need for effective faculty advising.

\section{Off-campus library services}

The Off-campus Library Services Confer ence, sponsored by the Central Michigan University Libraries and the Institute for Personal and Career Development, will be held in Charleston, South Carolina, October 20-21, 1988. Librarians, educators, administrators, and practitioners involved with adult learning programs or library services to off-campus students are invited to submit proposals for presentation. Proposals are sought on a variety of topics including but not limited to interlibrary cooperation, program administration, program evaluation including needs assessment, licensure questions, accreditation, uses of technology, remote delivery, copyright, student and faculty support services, and intrainstitutional cooperation

Persons interested in participating in the program are invited to send a titled abstract of not more than 500 words and a biographical statement of approximately 50 words to Maryhelen Garrett, Regional Librarian, Park Library 315 , Central Michigan University, Mt. Pleasant, MI 48859 ; (800) 248-9271, or in Michigan (800) 292-9076. Proposal evaluation will begin January 1,1988 
This caveat notwithstanding, the project clearly revealed that research in a modern university library requires access to new information and systematic training in integrating disparate areas of knowledge. As one of our participating faculty members commented on the training provided by the project, "the best of our students become even better."

${ }^{5}$ Professor Jerome Aumente, director of the Journalism Resources Institute, Rutgers University.

\section{ACRL executive summary}

\section{Professional development}

$N E H$. We held the 11th in our series of workshops co-sponsored with PLA and supported by NEH on public programming in the humanities. We have been invited to submit a proposal for another project. Sandy Donnelly is scheduling a meeting in San Antonio to discuss possible formats and co-sponsors.

WESS Florence Conference. Details have been worked out for an outstanding program. Excitement has been generated in Europe during a recent visit by Assunta Pisani. If you haven't received your mailing yet, please call JoAn Segal.

\section{Enhancing library service capahility}

$H B C U$ project. The planning conference for the Historically Black College and University (HBCU) Library Project was held in Atlanta on October 18-20, with 28 librarians attending. Beverly Lynch chaired the sessions. Keynote speaker Samuel Proctor urged the group to focus on the needs of students. The librarians were clear and specific about their needs and the directions they'd like ACRL to take. The Committee, which also includes Lorene Brown, Casper Jordan, Joe Howard, and Barbara Williams-Jenkins, met immediately following the session and made tentative plans to make a presentation to the ACRL leadership.

Output measures. The RFP for an author for the Output Measures Manual is "on the street." Mary Ellen Davis and the Ad Hoc Committee on Performance Measures prepared the piece with assistance from consultant Nancy van House. The Committee expects to select an author at Midwinter. Copies are available from Mary Ellen Davis.

\section{Liaison}

Grinnell meeting of college librarians. President Joanne Euster joined some fifty college librarians at their annual get-together, held October $18-20$ at Grinnell College. The program was full of practi$\mathrm{cal}$ and theoretical presentations of special interest to librarians of relatively large private liberal arts colleges.

\section{ALA events of interest}

COPES meeting. COPES met at ALA Head- quarters on October 26-28. They created two subcommittees: one to review indirect costs; another to consider the basic support to be provided to divisions under a new operating agreement, for which they hope to have a nearly final draft by Midwinter. COPES also said they would be reviewing and making recommendations on the total ALA budget, "including...Divisions," and "requiring that Management review and recommend Division budgets."

ALA Executive Board. Items on the agenda of particular interest to ACRL included:

SCOLE. An interesting discussion of the SCOLE suggestion regarding a statement on the MLS as the appropriate degree for librarians took place. Emphasis turned to defining what a " $\mathrm{Li}$ brarian" is, namely, a person with an MLS! SCOLE will continue work and come back at Midwinter.

Candidates' Forum. The Board voted to sponsor a candidates' forum for ALA President and Treasurer, beginning in San Antonio, and to invite all units to participate in this experimental program for this year. They also voted to have a special election supplement bound into American Libraries.

\section{ACRL Headquarters activities}

Quality circles. The training of staff in quality circle techniques has been proceeding nicely. Elaine Opalka is acting as trainer of the group; they are in the last phase of the training activity and about to select their first project. Membership in the circle is voluntary. We are all grateful to Elaine for her work on this and excited about what will emerge as more staff members begin to participate actively in managing work at ACRL.

Staffing work. The senior staff have been addressing the problem of work overload. We have used a process suggested in the publishing literature to identify and analyze tasks performed by ACRL staff members. We are also using the Matrix Management concept Joanne Euster presented at the ACRL Seattle Conference to identify which staff have what level of responsibility for each of the Goals and Strategic Management Directions contained in the plan. From this work we hope to be able to better define staffing needs. -JoAn S. Segal. 